\title{
Analysis of Agricultural Development in Hexi in Han Dynasty
}

\author{
Beibei Han \\ College of History and Culture \\ Northwest Normal University \\ Lanzhou, China 730070
}

\begin{abstract}
During the management in Hexi, Han government has a series of measures, such as setting up counties, emigrating people to remote areas, opening borders and reclaiming land, building water conservancy and protecting ecology. Under the above measures, the Han government has built Hexi Corridor from a nomadic area into a farming area, and these measures have effectively promoted the development and exploration of agriculture in Hexi Corridor in the Han Dynasty and ensured the smooth flow of trade from Chang'an to the Western Regions in the Han Dynasty, making business travel increasingly frequent and economic and cultural exchanges increasingly strengthened. In short, the agricultural development of the Hexi Corridor in the Han Dynasty is the fundamental condition for the economic prosperity of the Hexi in the Han Dynasty and the stability of the northwestern frontier.
\end{abstract}

\section{Keywords-Han Dynasty; Hexi; agricultural development}

\section{INTRODUCTION}

The research on agricultural development in Hexi in the Han Dynasty is mainly found in the following three articles, namely: Gao Rong's "Management of Agriculture in Hexi in the Western Han Dynasty" (in Journal of Zhangye Teachers College, 1991, No. 2) and "Water Conservancy Construction and Management in Hexi in Han Dynasty" (in "Journal of Dunhuang Studies", 2008, 02), Gao Xiaoqiang's "Development of Irrigation Agriculture in the Hexi Corridor during the Western Han Dynasty and Its Impact on the Ecological Environment" (in Journal of Shihezi University, 2010, 03). The above articles mainly use the handed-down literature to illustrate the agricultural development of Hexi in the Han Dynasty. However, the information on the agricultural science in Hexi in the Han Dynasty, such as Juyan Bamboo Slips of the Han Dynasty and Xuanquan Bamboo Slips in northwest China has not been fully utilized by the academic community for a long time. In view of this, this paper sorts out the relevant materials in the northwest unearthed literature about the development of agriculture in Hexi made by the Han government, and combines with the handed-down literature to discuss the measures adopted by Han government during the administration in Hexi, such as setting up counties, emigrating people to remote areas, opening borders and reclaiming land, building water conservancy and protecting ecology, in order to make a comprehensive interpretation and analysis of the agricultural development of the Hexi Corridor in the Han Dynasty.

\section{Setting UP Counties AND EmigRating PeOPle to REMOTE AREAS}

The Hexi Corridor is located in the northwestern part of Gansu Province, starting from Wushaoling in the east and ending in Dunhuang Yangguan and Yumen Pass in the west. The southern boundary is the Qilian Mountains while the northern boundary is Longshou Mountain, Heli Mountain and Maji Mountain. It is more than 1,000 kilometers long from east to west and about ten to 100 kilometers wide from north to south. It is named because of its corridor-like.shape Hexi was occupied by Xiongnu more than 2,000 years ago. After three large-scale wars of the Han government against Xiongnu, Hexi was under the command of the Han government.

\section{A. Setting up Counties}

The three large-scale wars launched by the Emperor Wu of the Han Dynasty against Xiongnu achieved a decisive victory, and finally Hexi was affiliated to the Han government. In order to effectively rule it and fundamentally cut off the "right arm" of Xiongnu and ensure the security of the northwestern border, the Han government set up four counties: Wuwei, Zhangye, Jiuquan and Dunhuang. The setting processes for the four counties are as follows:

The four counties in Hexi: The Han government set up Jiuquan County in the last year of Yuanshou (the first 118 years - the first 117 years) in the "old place" of two kings: Hunxie and Xiutu; Wuwei County was set up in the first year of Yuyuan Ding (the first 116 years - the first 115 years) in the eastern part of Jiuquan County; Zhangye County was set up in the sixth year of Yuan Ding (the first 111 years) centered on Zhangye and Lingju; the Emperor Wu of the Han Dynasty (the first 88 years) set up Dunhuang County in the west of Jiuquan County. The implementation of the county system in Hexi relieved the threat posed by Xiongnu to the Han government.

\section{B. Emigrating People to Remote Areas}

In the second year of the Emperor $\mathrm{Wu}$ (the first 121 years), "Jiuquan County was just set, and later the migrants 
were sent to enrich the region." [1]In the three years of Yuanfeng Emperor (108 BC), there are Di people rebelling in Wudu, so he sent some of Di people to Jiuquan County. In the second year of Zhenghe (91 BC), Liu Qumao migrated to Dunhuang County following the troops and officials sent by Prince. [2]In the third year of Taichu (102 BC), the Han government sent 180,000 troops to the north of Jiuquan County and Zhangye County, and set Juyan County and Xiutu County to defend Jiuquan County. [3]The people who traveled to Hexi were either poor people in the northeast China or outrageous people, and their families moved together. [4]

The immigrants' situation of Zhangye County was mainly after Zhaoxuan. According to the record in Juyan Bamboo Slips, "in the fifth year of Jianping when $\mathrm{Ai}$ Emperor of Han Dynasty was in office (2 BC), Qiu Zhang, lived in Shanju, wanted to buy a field belonging to non-local people. After the official inspection, Qiu Zhang's taxes and corvée are qualified, so clearance certificate was issued to Qiu Zhang according to the law and then they migrated to Juyan County." This bamboo slip records in the fifth year of Jianping when Ai Emperor of Han Dynasty was in office (2 BC), Qiu Zhang, who lived in Shanju, wanted to buy a field belonging to non-local people for him. After the official inspection, Qiu Zhang's taxes and corvée are qualified, so clearance certificate was issued to Qiu Zhang according to the law and then they migrated to Juyan County. There is a field belonging to non-local people, indicating that there are immigrants in the area. The non-local people who are not registered are called guests.

Immigrants brought a large amount of labor as well as advanced farming techniques of the Central Plains people, which provides the labor required for agricultural production. It was a necessary condition for the Han government to carry out agricultural development. The implementation of immigration has effectively promoted agricultural development in Hexi.

\section{THE IMPLEMENTATION OF RECLAIMING LAND AND THE DAITIAN METHOD}

\section{A. Reclaiming Land}

Han government carried out reclaiming land since the fifth year of Yuanding (112 BC) According to Hanshu records of food and goods, the Han government organized tens of thousands of people to cross the river to Lingju County. First they set up Zhangye County and Jiuquan County, then set up field official in Shang County, Shuofang County, Xihe and Hexi, and sent 600,000 people to the defend border. [5]And Historical Records Pingzhun Book recorded: In the next year (the fifth year of Yuanding, 112 BC), there are people rebelling in Nanyue and Qiang people invaded the frontier in the western. Thus, the emperor pardoned the prisoners, and sent more than 200,000 people in the south to attack Nanyue, tens of thousands of people to attack West Qiang, and tens of thousands of people to cross the river to the Lingju County. First they set up Zhangye County and Jiuquan County, then set up field official in
Shang County, Shuofang County, Xihe and Hexi, and sent 600,000 people to the defend border. [6]"

Book of the Later Han - records of hundreds of officials recorded: "Agriculture official was set in border county in charge of reclaiming land and farming" In the Juyan Bamboo slips, the organization system about reclaiming land organization is also common, such as the following slip records:

(1) On the day of Wuyan, February, Zhang Ye defended $\mathrm{Fu} \mathrm{ku}$, and when the prefecture chief reported works to agriculture official and military officer protecting field of Zhangye, he said according to the law, if the hidden goods is not...4.1

(2) On the day of Bingwu, March, the changshi of Zhang Ye, Shi Yan, acted on behalf of prefecture chief and the official of Jianshui warehouse, tang acted on behalf of the minister of Jianshui warehouse. The official of Jianshui warehouse, tang supervised the work according to the case to the state farmer's capital office. $4 \cdot 1$

(3) The lower-level department reports to the country's agriculture official that the wheat field is dry, and the wheat seedlings are mostly damaged, which is worrisome, and the responsibility lies in the state.EPT59:556

Three slips cited above respectively recorded the agricultural officials such as the agriculture officers, the officer protecting fields, and the state agriculture officers, all of which were set to protect agricultural production. In the Han Dynasty, the main places reclaiming lands include Zhangye Fanhe, Wuwei, Juyan and Dunhuang. According to Mr. Chen Mengjia's research, at that time, there were all agricultural officials in the 11 counties from Dunhuang to Xihe. [7]Mr. Liu Guanghua has carried out a deep research and summary of the personnel and system for reclaiming lands. The basic organization system of the specific production of reclaiming land is as follows: agriculture officer - farm order - Ministry of Agriculture - agriculture Tingzhang

These official positions correspond to the farmhouse, the field official, number $\mathrm{N}$ leader, and number $\mathrm{N}$ pavilion.

\section{B. Implementing the Daitian Method}

Since the implementation of Daitian method in the last years of the Emperor Wudi, this kind of agricultural farming method that is quite suitable for the arid regions in the northwest has been vigorously promoted in the production of the reclaiming land in northwest. Hanshu - records of food and goods recorded that the Han government organized manpower to teach the Daitian method to the people in border counties and Juyan County. After that, people in the border town, the Hedong area, the Hongnong County, and the Sanfu land used the field method to farm, which made people use less force and harvested more. This shows the promotion of Daitian method in the reclaiming system in the Hexibian County. This is especially true in the records of the "Daitian storehouse" and "Daitian leader" in Juyan Bamboo slips. For example: 
The income millet is 15 small stones. In the June of the third years of the Yuan Dynasty (84 BC), the second leader of Ting named Shu was assigned as the Daitian Warehouse Superviso. $273 \cdot 14$

Shu granted Daitian Cang zhang to provide food for 4 people. From Xinyou to Gengyin, they ate a total of 112 meals in a total of 28 days. $\quad 557 \cdot 6$

According to the research of Chen Zhi, the size of the Daitian warehouses set up for the emerging of Daitian method is the largest within the scope of Jianshui military rank. The variety of cereals is increasing and the output has increased after the implementation of Daitian method, which has contributed a lot to the supply of provisions for garrison army. [8]

Wind and drought resistance is a major problem that must be solved in traditional dry farming, and the Daitian method can make the seedlings fully absorb the water in the soil. This method of furrow exchange can also improve the ability of crops to resist wind and sand. The Daitian method was implemented in the arid areas such as the Frontier Fortress in Hexi to prevent drought and preserve the water, and the exchange of furrow of the Daitian ensures that the wasteland that has just been reclaimed has time to recuperate.

\section{WATER CONSERVANCY}

\section{A. Overview of the Hexi River}

Hexi is located inland, with a dry climate and little precipitation. The Qilian Mountains, which lie in the south of the corridor, have always been the source of life of the Hexi area. The three major river systems, Shiyang River, Heihe River and Shule River covering the whole of Hexi, originate from this.

Shiyang River, the two Hans called "Guishui." It is recorded in the Han Shu Geography Record that "Nanshan in Guzang County is Gushui. The valley water flows northward and flows into the river after reaching Wuwei, with the total length of 790 miles. Xiutu pond in the northeast is recorded in the ancient text as Zhuye pond. [9]

The Heihe River is called Ruoshui in Han Dynasty, and there are Qianggushui, Hucanshui and Qianjin Canal in the upstream. In Han Shu Geography Record, it is recorded that Qianjin canal flows westward to Leguan County and entered into Xiutu pond. The Qianggushui comes from the land of Qiangzhong, flows from the northeast to Juyan County and merges into Juyan Lake. It flows through two counties with a length of 2,100 miles. [10]"

Shule River was called Jiduanshui, Dang river or Dizhishui by Han people. In Dunhuang County part of Han Shu Geography Record, it is recorded that Jiduanshui, in the south of Jing'an County, was derived from the central part of Southern Qiang, which merged into the river from the northwest and irrigated the land. Dizhishui, derived from the central part of Southern Qiang, flowed into the river from the northeast and irrigated the land. [11]This indicates that there is a water conservancy project for diversion irrigation. The official of Shandan County, Sangqin believes that Ruoshui comes from Shandan County, and flows westward to the Heli Mountain in Jiuquan. Juyan Lake in Juyan County is in the northeast direction. In the ancient book, Juyan Lake is considered to be the river of sand. [12]And in Jiuquan County part, it is recorded that Hucanshui in Lufu County (now the Northern River) originated from the central part of Southern Qiang, which flowed into the Qianggushui from the northeast. [13]

\section{B. Water Conservancy}

Water conservancy irrigation is a prerequisite for agricultural production, and the Han government has built a large number of water conservancy projects. In the handeddown documents such as Han Shu Xiongnu Biography, it is recorded that "after the Han government soldiers crossed the river from Shuofang County and reached Lingju County in the west. They usually dig the canals and reclaim land, so the number of government officials and garrison soldiers reached 50,000 to 60,000." [14]

In the Dunhuang Xuanquan Han Bamboo Slips, there are also records about the people's building channels or the government's calling garrisons to help the people build the canals. The slip records for agricultural irrigation are:

- Huiguang is a captain for digging the canal. His private follower is Dushan who has four sheep. V92DXT1312(4): 21

- The people dig the canal by themselves, and the position is on the second left side and the second right side. The canal has a gate and it is 1.98 meters long and 6000 meters wide. II90DXT0213(3): 4

- Then they continue to dig the first channel. The port on the east side of the first channel is 1000 meters and 100 steps, and the length is between 4.39 meters and 10.91 meters. The depth is 3.41 meters to 26.64 meters. V92DXT1312(3): 17

- On the second day of one month, Xuanquan sent a Sefu named Hong to Yuanquan County, and transferred 21 garrison soldiers who had dig the canal. I90DXT0116(2): 117

- In the third year of Yuan Emperor in Han Dynasty (46 BC), a garrison soldier named Sheng helped the poor to dig the canal, which was registered in the books of Min'an County. V92DXT1410(3): 50

The above five slips were unearthed in Dunhuang Xuanquan Zhi, which recorded the water conservancy activities of the "digging canal". These garrison soldiers specially "digging canal" were called "soldiers for digging canal". All of the above are about the records of building canals, indicating that Hexi has become a key area for the construction of water conservancy. Water conservancy construction plays an extremely important role in promoting the reclaiming of land, which greatly promotes the agricultural development of Han government in Hexi and the development of dry farming in Hexi. 


\section{ECOLOGICAL PROTECTION}

On May 8, the fourth year of Jianwu in Guangwu Emperor of Han Dynasty (AD 28), Fang, in the position of officer of Jia canal replace the official business of Hou. According to the book, Fang said: government officials and people cannot cut trees, regardless of the four seasons. After the cautious inspection by the lower-level department, they should report to the higher-level department that there was no person cutting trees here. Tan, with the position of Zhuan recorded this matter. EPF22: 48

This is a report of the Han government's ban on cutting trees and a report on the implementation of this order. According to records, China has paid great attention to ecological protection since Qin Dynasty. For example, in Eighteen kinds of Qin law - law of field, it is recorded: "春二 月, 册敢伐材木山林及雍 (雍) 堤水。不夏月, 册敢夜 (择) 草为 灰, 取生荔、蝔（卵）、豰, 册 $\square \square \square \square \square \square \square$ 四毒鱼鳖, 置突周 （网）, 到七月而纵之。唯不幸死而伐绾（棺）享 (楟) 者, 是不用 时。” The general idea is that in the spring of February, the people are not allowed to cut trees in the forest, and the people are not allowed to block the waterways. Not until summer, people are not allowed to use burning grass or grass ash as fertilizer and pick buds. This ban will not be removed until July. Only when wood is needed to make coffin will cutting trees not restricted by the season.

Han government inherited the Qin system, so this slip is also a response and its title is lost. According to the content, it can be named as the slip for "Jia canal officer forbid cutting trees in May, the fourth year of Jianwu". The content of slip "no cutting trees" is one of the "words for four seasons". The preface on the wall of Xunquanzhi of Han Dynasty wrote "until August, people are forbidden to cut trees regardless of the size." When trees and grass fallen, people can cut those need to be cut." In Lv's Spring and Autumn - Meng Chunji", and "The Book of Rites - Order of the Moon" also means that in spring, "people are forbidden to cut", while in autumn, when "grass and trees are falling, people can cut trees to make coal." The relevant slip record also includes:

On May 8, the fourth year of Jianwu in Guangwu Emperor of Han Dynasty (AD 28), Fang, in the position of officer of Jia canal replace the official business of Hou. According to the book, Fang said: government officials and people cannot cut trees, regardless of the four seasons. After the cautious inspection by the lower-level department, they should report to the higher-level department that there was no person cutting trees here. Tan, with the position of Zhuan recorded this matter. EPF22: 53

This slip is also about the local officers conveying the order of emperor or Juyandu government. People and officers are strictly forbidden to deforest the trees, and the grassroots officers are required to report the implementation situation of the spring, summer, autumn and winter. From this point of view, from the central government to the local government, the Han government has put into action the law of "protecting the trees" that is beneficial to ecological environment protection.
In Juyan Han bamboo slip, the people were not allowed to violate the bans for four seasons to cut trees, which reflected the maintenance of the ecological environment by the Hexi authorities in the Han Dynasty. Moreover, the people under the jurisdiction of the Juyan Jia canal did not violate the ban for four seasons, which means "no violation of the ban for four seasons"; there was no people cutting tree, which refers to "no cutting trees". This reflected the important content of ecological protection in the Hexi area of the Han Dynasty.

\section{CONCLUSION}

Under the above measures, the Han government built Hexi from a nomadic area into a farming area. This is no longer the activity area of Xiongnu and there is no longer a lifestyle of "living with water and grass", but people settle down and carry out agricultural production. Because Hexi region in Han Dynasty belonged to the northwest border area of the Han Dynasty, it has a more prominent military nature. The Han government sent troops to defend the border throughout the year to prevent Xiongnu from invading again. The smooth flow of the Hexi Corridor ensured the smooth flow of trade from Chang'an to the Western Regions in the Han Dynasty. Economic and cultural exchanges are increasingly strengthened with the frequent business and trade.

The agricultural development of Hexi carried out by Han government made Hexi, Longxi and the mainland connected together, which greatly facilitated the economic and cultural exchange between Han and the Western Region. In the fourth year of the Yuan Ding (113 years ago), the Western Region began to connect with Han. After the Han government took the above measures, The Han government sent emissaries to Anxi country. Later, emissaries of Han and Western countries visited each other on the road. Every time there are hundreds of people at most, or scores of people at least. The things that the merchants bring are various and endless. The exchanges between merchants in Han and the countries of the Western Regions are endless. The above events cannot be attributed to the agricultural development made by Han government in Hexi Corridor.

The above historical facts show that farming production provides clothing and food security for the local military and civilians. The agricultural development of the Hexi Corridor in the Han Dynasty is the fundamental condition for the economic prosperity of the Hexi and the stability of the northwestern frontier in the Han Dynasty.

\section{REFERENCES}

[1] Han Shu. Volume 6, Wu Emperor [M]. Zhonghua Book Company, 1962: 194.

[2] Han Shu. Volume 66, Liu Qumao's Biography [M]. Zhonghua Book Company, 1962: 2882.

[3] Han Shu. Volume 61, Biography of Zhang Qian and Li Guangli [M]. Zhonghua Book Company, 1962: 2700.

[4] Han Shu. Second part of Volume 28, Geography Record[M]. Zhonghua Book Company, 1962: 1645. 
[5] Han Shu. Second part of Volume 24, records of food and goods [M]. Zhonghua Book Company, 1962: 1173.

[6] Historical Records. Volume 30, Pinghzhun Book [M]. Zhonghua Book Company, 1959: 1439.

[7] Chen Mengjia. Book of Han Bamboo Slips [M]. Zhonghua Book Company, 1980.

[8] Chen Zhi. Research on Juyan Han Bamboo Slips [M]. Tianjin Ancient Books Publishing House, 1986:26.

[9] Han Shu. Volume 28, Geography Records [M]. Zhonghua Book Company, 1962:1612.

[10] Han Shu. Volume 28, Geography Records [M]. Zhonghua Book Company, 1962:1613.

[11] Han Shu. Volume 28, Geography Records [M]. Zhonghua Book Company, 1962:1614.

[12] Han Shu. Volume 28, Geography Records[M]. Zhonghua Book Company, 1962:1613.

[13] Han Shu. Volume 28, Geography Records [M]. Zhonghua Book Company, 1962:1614.

[14] Han Shu. Volume 94, Xiongnu Memoirs [M]. Zhonghua Book Company, 1962: 3770.

[15] Han Shu. Volume 61, Biography of Zhang Qian and Li Guangli [M]. Zhonghua Book Company, 1962: 2694. 